\title{
Genetic characterization of 12 heterologous microsatellite markers for the giant tropical tree Cariniana legalis (Lecythidaceae)
}

\author{
Marcela Corbo Guidugli ${ }^{1}$, Klaus Alvaro Guerrieri Accoroni ${ }^{1}$, Moacyr Antonio Mestriner ${ }^{1}$, \\ Eucleia Primo Betioli Contel ${ }^{1}$, Carlos Alberto Martinez ${ }^{2}$ and Ana Lilia Alzate-Marin ${ }^{1}$ \\ ${ }^{1}$ Departamento de Genética, Faculdade de Medicina de Ribeirão Preto, Universidade de São Paulo, \\ Ribeirão Preto, SP, Brazil. \\ ${ }^{2}$ Departamento de Biologia, Faculdade de Filosofia Ciências e Letras de Ribeirão Preto, \\ Universidade de São Paulo, Ribeirão Preto, SP, Brazil.
}

\begin{abstract}
Twelve microsatellite loci previously developed in the tropical tree Cariniana estrellensis were genetically characterized in Cariniana legalis. Polymorphisms were assessed in $28 \mathrm{C}$. legalis individuals found between the Pardo and Mogi-Guaçu River basins in the state of São Paulo, Brazil. Of the 12 loci, 10 were polymorphic and exhibited Mendelian inheritance. The allelic richness at each locus ranged from 2-11, with an average of 7 alleles per locus, and the expected heterozygosity ranged from $0.07-0.88$. These loci showed a high probability of paternity exclusion. The characteristics of these heterologous microsatellite markers indicate that they are suitable tools for investigating questions concerning population genetics in $C$. legalis.
\end{abstract}

Key words: conservation, jequitibá rosa, population genetics, SSR markers, transferability.

Received: March 18, 2009; Accepted: July 1, 2009.

Cariniana legalis (Mart.) Kuntze, commonly known as jequitibá rosa, is a woody tree species of the Lecythidaceae family with late successional characteristics (Lorenzi, 2002). Its flowers are hermaphroditic and are pollinated by bees; dispersion is anemochorous (Sebbenn et $a l ., 2000)$. Jequitibá rosa is known as one of the giant trees of the Atlantic Rain Forest, reaching $60 \mathrm{~m}$ in height and $4 \mathrm{~m}$ in diameter (Kageyama et al., 2003). In Brazil, C. legalis wood is widely used for general construction purposes and carpentry (Lorenzi, 2002). Unfortunately, the C. legalis population has been dramatically reduced by habitat destruction and exploitation of its timber (Sebbenn et al., 2000). To develop strategies for the sustainable management and conservation of this species, an understanding of the effects of spatial isolation on genetic diversity and gene flow is crucial. Although allozymes have been surveyed in C. legalis for purposes such as assessing its mating system (Sebbenn et al., 2000), very little is known about the finescale population structure of this species.

Simple sequence repeat (SSR) markers have become the marker class of choice for population genetic studies because they are (mostly) co-dominant, abundant in

Send correspondence to Ana Lilia Alzate-Marin. Laboratório de Genética Vegetal, Departamento de Genética, Faculdade de Medicina de Ribeirão Preto, Universidade de São Paulo, Av. Bandeirantes 3900, 14049-900 Ribeirão Preto, SP, Brazil. E-mail: anaalzate@rge.fmrp.usp.br. genomes, highly reproducible, and some have high rates of transferability across species (Saha et al., 2006). The widespread use of microsatellites has been limited by the fact that the initial identification of the marker is expensive. Consequently, researchers have tried to use microsatellite markers developed for one species in other species by means of transferability analysis (Roa et al., 2000). Recently, Guidugli et al. (2008) developed 15 polymorphic microsatellite markers for Cariniana estrellensis and demonstrated the transferability of 12 of these primer pairs to $C$. legalis based on amplification of just seven individuals. Therefore, in this study, characteristics of 12 heterologous loci were investigated using $28 \mathrm{C}$. legalis individuals in order to confirm the general applicability of these markers for genetic studies of this species.

For the genetic analysis, we collected leaves from 28 reproductive $C$. legalis adults located between the Pardo and Mogi-Guaçu River basins in the state of São Paulo in southeastern Brazil. This large area, the Ribeirão Preto region, is highly impacted by agricultural practices (Figure 1). The collection of leaves from the tall trees was a very laborious task, requiring the employment of specialized tree climbers. The geographic coordinates of all sampled individuals were recorded using GPS (GARMIN eTrex ${ }^{\circledR}$ Vista $\mathrm{Cx}$ ), and the plant tissues were stored at $-20{ }^{\circ} \mathrm{C}$ until DNA extraction. Total genomic DNA was extracted from frozen leaf tissues based on the protocol described by 


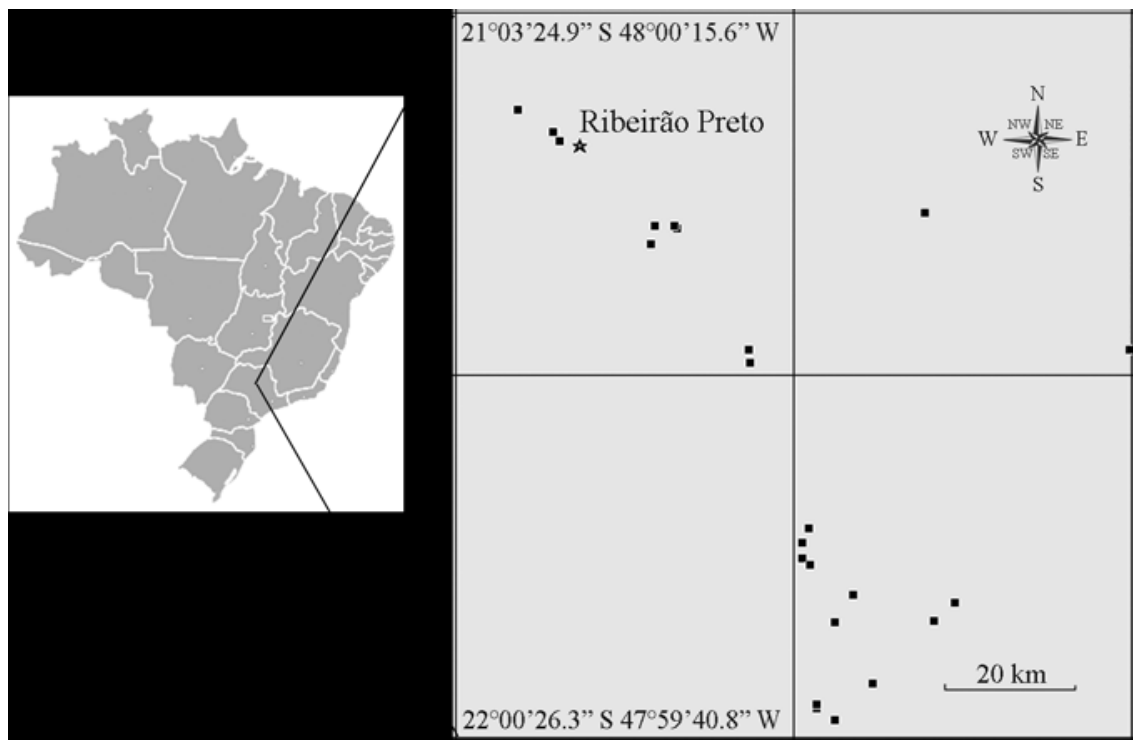

Figure 1 - Geographic location of the Cariniana legalis individuals sampled in southeastern Brazil for assessment by SSR loci.

Doyle and Doyle (1990), with minor modifications. Purity and concentration of the genomic DNA were determined with a spectrophotometer (Spectronic Genesys 5).

Each primer pair previously transferred to C. legalis from C. estrellensis (Guidugli et al., 2008) was screened with polymerase chain reactions (PCR) at 13 annealing temperatures (between $46-58^{\circ} \mathrm{C}$ ) in 10 C. legalis individuals in order to optimize heterologous amplification. PCR amplifications were carried out in a final reaction volume of $10 \mu \mathrm{L}$ containing $0.3 \mu \mathrm{M}$ of each primer, $1 \mathrm{U}$ Taq DNA polymerase, $0.25 \mathrm{mM}$ of each $\mathrm{dNTP}, 1 \times \mathrm{MgCl}_{2}$-free reaction buffer $[75 \mathrm{mM}$ Tris- $\mathrm{HCl} \mathrm{pH} 9.0,50 \mathrm{mM} \mathrm{KCl}$ and $\left.20 \mathrm{mM}\left(\mathrm{NH}_{4}\right)_{2} \mathrm{SO}_{4}\right], 1.5 \mathrm{mM} \mathrm{MgCl}_{2}$ and $2.5 \mathrm{ng}$ of template DNA. Amplifications were performed in a MasterCycler (Eppendorf) according to the following protocol: $5 \mathrm{~min}$ at $96{ }^{\circ} \mathrm{C}$ followed by 30 cycles of $30 \mathrm{~s}$ at $94{ }^{\circ} \mathrm{C} ; 1 \mathrm{~min}$ at the annealing temperature defined for each primer (Table 1); $1 \mathrm{~min}$ at $72{ }^{\circ} \mathrm{C}$; and a final elongation step of $7 \mathrm{~min}$ at $72{ }^{\circ} \mathrm{C}$. PCR products were denatured and separated on $10 \%$ denaturing polyacrylamide gels stained with silver nitrate. Allele sizes were estimated using a DNA ladder (10 bp Invitrogen) and the original DNA clone from which the SSR locus was developed.

Mendelian inheritance was investigated for each locus based on analysis of one mother tree and 20 openpollinated offspring. Polymorphic loci were characterized with regard to the number of alleles per locus $(A)$, as well as expected $\left(H_{\mathrm{E}}\right)$ and observed $\left(H_{\mathrm{O}}\right)$ heterozygosities for each locus and averaged over all loci, using the GDA software (Lewis and Zaykin, 2002). Hardy-Weinberg equilibrium was tested by Fisher's exact test. FSTAT software package version 2.9.3.2 (Goudet, 2002) was used to test linkage disequilibrium for all loci, applying the Bonferroni correction for multiple comparisons (Rice, 1989). Probabilities of paternity exclusion were estimated using CERVUS version
3.0 (Kalinowski et al., 2007). We also checked the presence of null alleles using the MICRO-CHECKER 2.2.3 program (van Oosterhout et al., 2004).

Our results confirmed the amplification efficiency of the 12 heterologous microsatellite markers for C. legalis. Of these, two (16.7\%) were monomorphic in the sample of 28 individuals, and the other 10 were polymorphic, showing clear allele size variation (Table 1). Satisfactory amplification products were obtained using eight annealing temperatures ranging from $46-57{ }^{\circ} \mathrm{C}$ (Table 1). Mendelian inheritance was verified for all 10 SSR loci in the openpollinated family. All siblings displayed at least one of the maternal alleles, confirming Mendelian inheritance.

A total of 70 alleles were found at the ten polymorphic microsatellite loci in the 28 reproductive adults. The number of alleles detected in this species ranged from 2 (Ces02) to 11 (Ces03) (Table 1). Most of the successful loci exhibited less allelic variation than was found in the species from which they were developed (average $=8.5$; Guidugli et al., 2008). The patterns described above are consistent with earlier studies showing reduced polymorphism in target species as compared to source species in cross-species amplification studies (Ciampi et al., 2008; Feres et al., 2009). According to Peakall et al. (1998), related products amplified in different species might include mutations, rearrangements and duplications in the flanking region, causing changes in the number of repeats, which could cause the reduction in polymorphism.

The average observed heterozygosity was 0.32 , and expected heterozygosities ranged from 0.07 to 0.88 across loci, with an average of 0.64 (Table 1). This value for average expected heterozygosity in $C$. legalis is higher than that in other tropical trees: Carapa guianensis $\left(H_{\mathrm{E}}=0.61\right.$, Dayanandan et al., 1999), Swietenia humilis $\left(H_{\mathrm{E}}=0.53\right.$, White et al., 1999) and Solanum lycocarpum $\left(H_{\mathrm{E}}=0.33\right.$, 
Table 1 - Characteristics of 12 heterologous microsatellite markers for Cariniana legalis.

\begin{tabular}{|c|c|c|c|c|c|c|c|c|c|c|}
\hline $\begin{array}{l}\text { Primer } \\
\text { name }\end{array}$ & $\begin{array}{l}\text { Accession } \\
\text { number }\end{array}$ & Primer sequence 5'-3' & $\begin{array}{l}\text { Observed fragment } \\
\text { size range }(\mathrm{bp})\end{array}$ & $\begin{array}{c}\mathrm{Ta} \\
\left({ }^{\circ} \mathrm{C}\right)\end{array}$ & $A$ & $H_{\mathrm{O}}$ & $H_{\mathrm{E}}$ & $\operatorname{Pr}(E x 1)$ & $\operatorname{Pr}(E x 2)$ & $\begin{array}{l}\text { Dev. } \\
\text { HWE }\end{array}$ \\
\hline Ces02 & EU735166 & $\begin{array}{l}\text { F:GGACATGGGTTGTTATCCG } \\
\text { R:TCTCAACCTCAAAATGTAATAGC }\end{array}$ & $163-165$ & 57 & 2 & 0 & 0.07 & 0.998 & 0.967 & 0.021 \\
\hline Ces03 & EU735167 & $\begin{array}{l}\text { F:GGTGTATCCTAAGGTAGAGC } \\
\text { R:CCTTTGGAAGATATGGAAG }\end{array}$ & $207-235$ & 50 & 11 & 0.50 & 0.86 & 0.460 & 0.297 & $<0.001$ \\
\hline Ces05 & EU735169 & $\begin{array}{l}\text { F:CCAGATTGATAAGCTACTCC } \\
\text { R:CATTCAAGCAAGTCAAACC }\end{array}$ & $149-163$ & 53 & 6 & 0.43 & 0.73 & 0.680 & 0.501 & $<0.001$ \\
\hline Ces06 & EU735170 & $\begin{array}{l}\text { F:GGGGCATATGTTTATTATTC } \\
\text { R:GTGGTAAATCACAAATGTGC }\end{array}$ & 159 & 51 & 1 & - & - & - & - & - \\
\hline Ces07 & EU735171 & $\begin{array}{l}\text { F:TTGTAAAAACGGCATGTCC } \\
\text { R:GTTCGGAACAGACAAAGAGG }\end{array}$ & $178-202$ & 51 & 10 & 0.74 & 0.87 & 0.451 & 0.289 & 0.009 \\
\hline Ces09 & EU735172 & $\begin{array}{l}\text { F:CAGAGTTTTTCAATAGCGG } \\
\text { R:TTTCATTGCAATCATAGGC }\end{array}$ & 185 & 48 & 1 & - & - & - & - & - \\
\hline Ces10 & EU735173 & $\begin{array}{l}\text { F:GGGCAGACCAAATCAAGAG } \\
\text { R:GCCATTCATAAACCATTCAAG }\end{array}$ & $196-228$ & 49 & 6 & 0.44 & 0.59 & 0.799 & 0.621 & 0.013 \\
\hline Ces12 & EU735175 & $\begin{array}{l}\text { F:ACGCACTTTCTCAATTCC } \\
\text { R:TGTAGACTTGTAGGATAAATGG }\end{array}$ & $265-287$ & 46 & 10 & 0.26 & 0.88 & 0.417 & 0.261 & $<0.001$ \\
\hline Ces13 & EU735176 & $\begin{array}{l}\text { F:CTGAAGGGACTGAGGGG } \\
\text { R:ATATCAGGAGGTTAAGGGC }\end{array}$ & $142-156$ & 47 & 5 & 0.16 & 0.59 & 0.817 & 0.680 & $<0.001$ \\
\hline Ces14 & EU735177 & $\begin{array}{l}\text { F:CTGGTAAGCTCTTGGTTGTG } \\
\text { R:CCATGGGTTTTCTGTTTCC }\end{array}$ & $180-186$ & 51 & 4 & 0.24 & 0.29 & 0.958 & 0.846 & 0.254 \\
\hline Ces16 & EU735178 & $\begin{array}{l}\text { F:GGACATACCTGCCAAAAC } \\
\text { R:AGAGTTAGTTGCTGTTATATGG }\end{array}$ & $204-214$ & 51 & 6 & 0.07 & 0.71 & 0.695 & 0.514 & $<0.001$ \\
\hline Ces18 & EU735179 & $\begin{array}{l}\text { F:ATAATCATGACCTGTGCC } \\
\text { R:GTCCCTGATCAAGTATGC }\end{array}$ & $166-186$ & 51 & 10 & 0.40 & 0.84 & 0.499 & 0.330 & $<0.001$ \\
\hline \multicolumn{6}{|c|}{ Average ${ }^{1} /$ Cumulative probability of exclusion ${ }^{2}$} & $0.32^{1}$ & $0.64^{1}$ & $0.872^{2}$ & $0.999^{2}$ & \\
\hline
\end{tabular}

$\mathrm{Ta}^{\circ} \mathrm{C}$, annealing temperature; $A$, total number of alleles per locus; $H_{\mathrm{O}}$, observed heterozygosity; $H_{\mathrm{E}}$, expected heterozygosity; $\operatorname{Pr}(\operatorname{Ex} 1)$ and $\operatorname{Pr}(\operatorname{Ex2})$, paternity exclusion probabilities; HWE, Hardy-Weinberg equilibrium; Significance $(\mathrm{p}<0.05)$.

Dev. HWE: deviation from HWE.

Martins et al., 2006). A heterozygote deficiency was observed for the majority of loci, most likely due to the sampling of individuals used for locus characterization (the Wahlund effect) or the presence of null alleles. In fact, the null allele test (MICRO-CHECKER, van Oosterhout et al., 2004) revealed that several loci (Ces02, Ces03, Ces05, Ces12, Ces13, Ces16 and Ces18) showed evidence of null alleles. Furthermore, because the results were obtained using microsatellites developed in a different species, the probability of occurrence of a null allele is much higher than in the case of testing the species from which they were isolated (Kim et al., 2004).

For all loci except Ces14, the genotypic frequencies showed significant departures from Hardy-Weinberg equilibrium (HWE). None of the loci showed significant linkage disequilibrium after a sequential Bonferroni correction for multiple tests, indicating that these markers are appropriate for population genetics studies. The SSR profiles generated by the ten heterologous primer pairs were able to distinguish all 28 C. legalis individuals sampled in southeastern Brazil. The first estimate of paternity exclusion probability $\operatorname{Pr}(E x 1)$, when the offspring was sampled but the mother was not, was 0.872 for the combined loci. The second estimate, $\operatorname{Pr}(E x 2)$, when both the mother and the offspring were sampled, was 0.999 over all 10 loci (Table 1). The combined probabilities of paternity exclusion were very high, demonstrating that these markers represent an important tool that will permit more refined and challenging questions regarding gene flow and parentage in natural populations of $C$. legalis to be addressed.

In conclusion, this study characterized a novel set of heterologous microsatellite markers for $C$. legalis. These markers provide a new approach for generating fundamental data important for devising sound conservation procedures for this species.

\section{Acknowledgments}

This study was supported by FAPESP (A.L.A.M. \#03/04199-4), Research Pro-Rectory of São Paulo University (A.L.A.M.) and FAEPA (M.A.M.) grants. This study is part of the graduate work of first author. A.L.A.M. was supported by a researcher assistantship from $\mathrm{CNPq}$ (PD Senior 150277/2009-1). C.A.M. is a fellow researcher of CNPq. M.C.G. and K.A.G.A. were supported by FAPESP fellowships. A.L.A.M., M.A.M. and C.A.M. are CEEFLORUSP members. 


\section{References}

Ciampi AY, Azevedo VCR, Gaiotto FA, Ramos ACS and Lovato MB (2008) Isolation and characterization of microsatellite loci for Hymenaea courbaril and transferability to Hymenaea stigonocarpa, two tropical timber species. Mol Ecol Res 8:1074-1077.

Dayanandan S, Dole J, Bawa K and Kesseli R (1999) Population structure delineated with microsatellite markers in fragmented populations of a tropical tree, Carapa guianensis (Meliaceae). Mol Ecol 8:1585-1592.

Doyle JJ and Doyle JL (1990) Isolation of plant DNA from fresh tissue. Focus 12:13-15.

Feres JM, Martinez MLL, Martinez CA, Mestriner MA and Alzate-Marin AL (2009) Transferability and characterization of nine microsatellite markers for the tropical tree species Tabebuia roseo-alba. Mol Ecol Res 9:434-437.

Guidugli MC, Campos T, Sousa ACB, Feres JM, Sebbenn AM, Mestriner MA, Contel EPB and Alzate-Marin AL (2008) Development and characterization of 15 microsatellite loci for Cariniana estrellensis and transferability to Cariniana legalis, two endangered tropical tree species. Conserv Genet 10:1001-1004.

Kageyama PY, Sebbenn AM, Ribas LA, Gandara FB, Castellen M, Perecim MB and Vencovsky R (2003) Genetic diversity in tropical tree species from different successional stages determined with genetic markers. Sci For 64:93-107.

Kalinowski ST, Taper ML and Marshall TC (2007) Revising how the computer program CERVUS accommodates genotyping error increases success in paternity assignment. Mol Ecol 16:1099-1106.

Kim KS, Min MS, An JH and Lee H (2004) Cross-species amplification of Bovidae microsatellites and low diversity of the endangered Korean Goral. J Hered 95:521-525.

Lorenzi H (2002) Árvores Brasileiras: Manual de Identificação e Cultivo das Plantas Arbóreas do Brasil. 4th edition. Instituto Plantarum, Nova Odessa, 368 pp.

Martins K, Chaves LJ, Buso GSC and Kageyama PY (2006) Mating system and fine-scale spatial genetic structure of Solanum lycocarpum St. Hil. (Solanaceae) in the Brazilian Cerrado. Conserv Genet 7:957-969.
Peakall R, Gilmore S, Keys W, Morgante M and Rafalski A (1998) Cross species amplification of soybean (Glycine max) simple-sequence-repeats (SSRs) within the genera and other legume genera: Implications for the transferability of SSRs in plants. Mol Biol Evol 15:1275-1287.

Rice WR (1989) Analyzing tables of statistical tests. Evolution 43:223-225.

Roa AC, Chavarriaga-Aguirre P, Duque MC, Maya MM, Bonierbale MW, Iglesias C and Tohme J (2000) Cross-species amplification of Cassava (Manihot esculenta) (Euphorbiaceae) microsatellites: Allelis polymorphism and degree of relationship. Am J Bot 87:1647-1655.

Saha MC, Cooper JD, Mian MAR, Chekhovskiy K and May GD (2006) Tall fescue genomic SSR markers: Development and transferability across multiple grass species. Theor Appl Genet 113:1449-1458.

Sebbenn AM, Kageyama PY, Siqueira ACMF and Zanatto ACS (2000) Mating system in populations of Cariniana legalis Mart. O. Ktze: Implications for genetics conservation and improvement. Sci For 58:25-40.

van Oosterhout C, Hutchinson WF, Wills DP and Shipley P (2004) MICRO-CHECKER: Software for identifying and correcting genotyping errors in microsatellite data. Mol Ecol Notes 4:535-538.

White GM, Boshier DH and Powell W (1999) Genetic variation within a fragmented population of Swietenia humilis. Zucc. Mol Ecol 8:1899-1909.

\section{Internet Resources}

Lewis PO and Zaykin D (2002) Genetic data analysis: Computer program for the analysis of allelic data, v. 1.1 . http://hydrodictyon.eeb.uconn.edu/people/plewis/software.php (January 20, 2009).

Goudet J (2002) FSTAT Software, v. 2.9.3.2. http://www2.unil.ch/popgen/softwares/fstat.htm (February 17, 2009).

Associate Editor: Márcio de Castro Silva Filho

License information: This is an open-access article distributed under the terms of the Creative Commons Attribution License, which permits unrestricted use, distribution, and reproduction in any medium, provided the original work is properly cited. 